\title{
PENGARUH INISIASI MENYUSU DINI TERHADAP INVOLUSI UTERUS PADA IBU POSTPARTUM
}

\section{Desideria Yosepha Ginting ${ }^{1}$, Safria Nirwana ${ }^{2}$, Arfah May Sara ${ }^{3}$, Layari Tarigan ${ }^{4}$, David Ginting ${ }^{5}$}

\author{
Institut Kesehatan Medistra Lubuk Pakam \\ Jl. Sudirman No. 38 Lubuk Pakam \\ e-mail: desideriayosepha.ginting@gmail.com \\ DOI : https://doi.org/10.35451/jkk.v2i2.389
}

\begin{abstract}
Early Breastfeeding Initiation is the process of breastfeeding babies as soon as they are born and can not be postponed by weighing or measuring the baby. The purpose of this study was to determine the effect of Early Breastfeeding Initiation on uterine involution in postpartum mothers. This type of research is Quarsi Experimental Design with observation research. the population in this study were all postpartum mothers at Tutun Sehati Tanjung Morawa's Clinic Deli Serdang Regency. Samples taken amounted to 10 people, used with observation techniques, which were divided into two groups, namely control (which was not given Early Breastfeeding Initiation) and intervention (given IMD). The result that the average Uterine Revolution in postpartum mothers who were controlled was 11.40 with a standard deviation of 0.54 . while the intervention group performed by Early Breastfeeding Initiation was 9.20 with a standard deviation of 0.47. so there is an effect of Early Breastfeeding Initiation on uterine involution in postpartum mothers with a $p$-value $=0.003$ $(P<0.05)$, It is recommended that health workers do Early Breastfeeding Initiation to postpartum mothers to accelerate the decrease in uterine involution.
\end{abstract}

Keywords: Early Breasfeeding Initiation, unterine involution, Postpartum

\section{PENDAhUlUAN}

World Health Organization (WHO) memperkirakan bahwa sekitar $15 \%$ dari seluruh wanita yang hamil akan berpotensi mengalami komplikasi yang berkaitan dengan kehamilan, sertadapat mengancam jiwa ibu danjanin (Feryanto, 2011). Data Indonesia penyebab kematian ibu melahirkan, diketahui bahwa pendarahan (28\%), Eklamsia (24\%), infeksi $(11 \%)$ dan komplikasi masa nifas (8\%) (Depkes RI, 2015).
Komplikasi masa nifas menjadi salah satu penyebab kematian ibu melahirkan maka pemerintah dalam upaya pencegahanya menyusun kebijakan program nasional masa nifas melalui empat kali kunjungan masa nifas, kunjungan masa nifas antara 6-8 jam setelah persalinan, 6 hari setelah persalinan, 2 dan 6 minggu setelah persalinan. program ini untuk menilai status ibu dan bayi baru lahir, untuk mencegah, mendeteksi, dan mengalami masa-masa yang terjadi perhatian dalam masa nifas itu tersebut adalah pemberian inisiasi menyusui dini di 
dalam 1 jam kelahiran dan memastikan infolusi uterus berjalan normal (Kemenkes, 2014).

Inisiasi menyusu dini atau (IMD) merupakan proses bayi menyusu segerah setelah dilahirkan selama 1 jam, IMD merupakan salah satu faktor yang mempengaruhi involusi uterus karena saat menyusui terjadinya rangsangan dan dikeluarkan olah hormone antar lain oksitosin yang berpungsi selain merangsang kontraksi otot-otot polos payudara, juga menyebabkan terjadinya kontraksi dan retraksi otot uterus. $\mathrm{Hal}$ ini akan menekan pembuluh darah yang mengakibatkan berkurangnya sublai darah ke uterus. Peroses ini membantu untuk menguranggi situs atau tempat implantasi plasenta serta mengurangi perdarahan (Mochtar, 2010)

Menurut Praborini (2008) dalam Nelwati (2013) ibu yang melakukan inisiasi menyusui dini akan mempercepat terjadi nya involusi uterus karena pengaruh hormon oksitosin yang dapat meningkat kan kontraksi uterus. Cakupan pemberian ASI Ekslusif di dunia dilihat berdasarkan regionnya diketahui pencapaian di afrika tengah banyak 25\%, Amerika latin dan karibia sebanyak 32\%, Asia timur sebanyak 30\%, Asia selatan sebanyak $4 \%$ dan di negarah berkembang sebanyak 46\%. Secara keseluruhan, kurang dari $40 \%$ anak dibawah usia enam bulan diberi ASI Ekslusif (WHO, 2017). Sedangkan data UNICEF tahun 2015 menyebutkan bahwa angka cakupan praktis inisiasi menyusui dini di dunia sebesar $42 \%$ dalam kurun waktu 2010-2015. Prevalensi inisiasi menyusui dini Indonesia sendri masih lebih rendah yaitu 49,3\% (SDKI, 2012). Pada tahun 2013 terjadi penurunan persentasi ibu yang melakukan inisiasi menyusui dini yaitu 34,5\% (Riskesdas, 2013). Angka ini masih sangat rendah jika di banding kan dengan negara lain di sebagian negara Asia tenggara misalnya Myanmar (76\%), Thailand (50\%), dan Filipina (45\%) (UNICEF, 2013).

Berdasarkan fenomena yang ada, data pelaksanaan pemberian ASI Ekslusif di Indonesia sendri masih tergolong jauh dari target sebesar $80 \%$. dan survey dasar Kesehatan indonesia (SDKI) 2012 menunjuk kan bahwa dari $96 \%$ bayi usia dibawah dua tahun yang perna disusuhanya sebanyak $42 \%$ usia 0-6 bulan yang di susuan cara Ekslusif (SDKI, 2012). Sedangkan pada tahun 2015 pemberian ASI Ekslusif di Indonesia mengalami penurunan hanya sebasar 41,9\% (Ditjen kesehatan masyarakat Kemenkes RI, 2016).

Menurut Provinsi, Cakupan ASI ekslusif pada bayi pada usia enam bulan paling besar berada di Sumatra utara sebesar 12,4\%, Gorontlosebesar $12,5 \%$ yang paling tinggi di jogyakarta sebesar 55,4\%. Sementara kondisi di Sumatra barat di dapat kan pemberian ASI ekslusif sebesar 37,6\% (Data dan Informasi Profil Kesehatan Indonesia, 2017).

Jika dilihat pencapaian IMD berdasarkan provinsi di indonesia di ketahui dengan pencapaian rendah yaitu di provinsi papua barat $(21,7 \%)$, Nusa tenggara barat (42,9\%), Maluku $(41,5 \%)$, Sulawesi tengah $(43,7 \%)$, Sumatra utara (44\%) dan Sumatra barat $(44,2 \%)$ ibu yang melakukan kegiatan IMD padabanyinya (Riskesdas,2013).

Penelitian Edmond (2006) diketahui ibu yang melakukan inisiasi menyusui dini dimulai pada hari pertama kelahiran yaitu $71 \%$.resiko komplikasi mas nifas 3,5 kali lebih tinggi pada ibu yang tidak melakukan inisiasi menyusu dini pada 24 jam pertama melahirkan dan semakin berkurang hingga 7 hari setelah melahirkan selain dari pada turesiko 
kematian neonatal empat kali lebih tinggi pada anak-anak diberi selain ASI.

Berdasar hasil penelitian Nelwatri (2013) diketahui bahwa terjadi penurunan fundus uteri pada ibu nifas hari keenam yang dilakukan inisiasi menyusui dini (IMD) adalah 10,54$1,103 \mathrm{~cm}$ sedangkan tinggi fundus uteri pada ibu nifas yang tidak dilakukan IMD adalah 13,33-1,129 cm. Hasil ini menunjukkan penurunan tinggi fundus uterus sekitar $2,79 \mathrm{~cm}$ pada ibu yang melakukan IMD dibandingkan yang tidak . penelitian Sari (2014) diketahui bahwa ibu yang melakukan inisiasi menyusui dini diketahui rata tinggi fundus ibu 2 jam postpartum adalah 11,8-0,73 cm, sedangkan yang tidak melakukan inisiasi menyusui dini yaitu $12,85-0,38 \mathrm{~cm}$, hasil penelitian ini terjadi penurunan tinggi fundus uteri ibu 2 jam postpartum setelah melakukan inisiasi menyusi dini sebesar $1,05 \mathrm{~cm}$ jika dibandingkan dengan ibu yang tidak melakukan inisiasi menyusui dini.

\section{METODE}

Design pada penelitian ini menggunakan Quasi Eksperimen Design dengan pendekatan static Group Comparison/Posttest Only Control Group Designs yang dilakukan di Klinik Tutun Sehati pada bulan Juni Tahun 2019. Populasi penelitian ini adalah seluruh ibu postpartum di Klinik Tutun Sehati pada bulan Juni 2019. Sampel penelitian ini adalah 20 orang ibu postpartum dengan kriteria ibu bersalin spontan dan tidak mengalami komplikasi, dengan tekhnik pengambilan sampel accidental sampling. Pengambilan data dilakukan dengan lembar observasi hasil pengukuran involusi uteri pada kelompok perlakuan dan kelompok kontrol. Analisa data menggunakan uji non-parametric yaitu uji Wilcoxon
Signed Rank Test dengan nilai alpha 0,05 .

\section{HASIL}

Tabel 1 Rerata Hasil Pengukuran Involusi Uterus pada Kelompok Kontrol

\begin{tabular}{ccc}
\hline $\begin{array}{c}\text { Frekuensi } \\
(\mathrm{N})\end{array}$ & $\begin{array}{c}\text { Mean } \\
(\mathrm{cm})\end{array}$ & $\begin{array}{c}\text { Standar } \\
\text { Deviasi }(\mathrm{SD})\end{array}$ \\
\hline 10 & $11,30 \mathrm{c}$ & 0,48 \\
\hline
\end{tabular}

Berdasarkan tabel 1 dapat dilihat hasil rerata hasil pengukuran Involusi Uterus pada kelompok control sebesar $11,30 \mathrm{~cm}$ dengan standar deviasi 0,48.

Tabel 2 Rerata Hasil Pengukuran Involusi Uterus pada Kelompok Intervensi

\begin{tabular}{ccc}
\hline Frekuensi (N) & $\begin{array}{c}\text { Mean } \\
(\mathrm{cm})\end{array}$ & $\begin{array}{c}\text { Standar } \\
\text { Deviasi } \\
(\mathrm{SD})\end{array}$ \\
\hline 10 & 9,30 & 0,48 \\
\hline
\end{tabular}

Berdasarkan tabel 2 rerata hasil pengurukuran involusi uteri pada kelompok intervensi sebesar $9,30 \mathrm{~cm}$ dengan standar deviasi 0,48.

Tabel 3 Perbedaan Rerata Hasil Pengukuran Involusi Uteri pada Kelompok Kontrol dan Kelompok Intervensi

\begin{tabular}{ccccc}
\hline Variabel & $\mathrm{N}$ & Mean & $\begin{array}{c}\text { Min- } \\
\text { Max }\end{array}$ & $\begin{array}{c}\mathrm{p}- \\
\text { value }\end{array}$ \\
\cline { 1 - 4 } Kontrol & 10 & 11,30 & $\begin{array}{c}11- \\
12\end{array}$ & 0,003 \\
\cline { 1 - 4 } Intervensi & 10 & 9,30 & $9-10$ & \\
\hline
\end{tabular}

Berdasarkan tabel 3 menunjuk kan nilai rata-rata involusi uterus pada ibu postpartum dengan analisis uji Wilcoxon dengan nilai $a=0,05$ yaitu di dapat kan nilai signifikan 0.003 ( $p$ value $<0,05)$. 


\section{PEMBAHASAN}

Proses Involusi uteri sangat dipengaruhi oleh beberapa factor, yaitu laktasi, mobilisasi dan nutrisi. Salah satu untuk membantu proses involusi dengan melakukan Inisiasi Menyusu Dini (IMD). Proses IMD dapat merangsang produksi hormon oksitosin melalui isapan bayi yang dapat merangsang kontraksi pada otot polos (Dewi, Vivian Nanny Lia, Sunarsih, Tri. 2011).

Hasil penelitian yang dilakukan pada kelompok kontrol atau kelompok yang tidak diberikan intervensi didapatkan rerata hasil pengukuran involusi uteri sebesar $11,30 \mathrm{~cm}$ dan standar deiasi sebesar 0,48 . Penelitian ini sejalan dengan hasil penelitian Nelwatri (2013) diketahui bahwa terjadi penurunan fundus uteri pada ibu nifas hari keenam yang dilakukan inisiasi menyusui dini (IMD) adalah 10,54-1,103 cm sedangkan tinggi fundus uteri pada ibu nifas yang tidak dilakukan IMD adalah 13,33-1,129 cm.

Menurut asumsi penulis, kurangnya proses kembalinya tinggi fundus uteri ini dipengaruhi oleh kurangnya produksi hormone oksitosin, sehingga kontraksi yang terjadi pada otot polos juga tidak optimal. Sedangkan pada hasil penelitian yang dilakukan pada kelompok intervensi atau kelompok yang mendapatkan perlakuan Inisiasi Menyusu Dini (IMD), didapatkan hasil rerata tinggi fundus uteri sebesar 9,30 $\mathrm{cm}$ dengan standar deviasi 0,48.

Hal ini diperkuat dengan penelitian sari (2014), diketahui bahwa ibu yang melakukan Inisiasi Menyusu Dini diketahui rata tinggi fundus dua jam postpartum adalah $11,8-0,8 \mathrm{~cm}$, sedangkan yang tidak melakukan Inisiasi Menyusu Dini 12,85-0,2 cm hasil ini terjadi penurunan fundus uterus selama dua jam sebesar 1,05 cm, jika dibandingkan dengan yang tidak melakukan Inisiasi Menyusu Dini.

Menurut asumsi peneliti, bahwa dengan dilakukkannya Inisiasi Menyusu Dini pada bayi segera setelah lahir sangat efektif dalam proses involusi uteri. Karena saat terjadi isapan yang dilakukan oleh mulut bayi pada putting susu ibu, maka stimulus isapan bayi akan mempengaruhi hipotalamus untuk memproduksi hormon oksitosin. Dengan meningkatnya produksi hormone oksitosin maka ini kan merangsang kontraksi dan retraksi pada otot polos, sehingga proses penurunan tinggi fundus uteri menjadi lebih cepat.

Berdasarkan hasil penelitian ini di dapat kan bahwa adanya perbedaan yang signifikan antara involusi uterus pada kelompok kontrol dan kelompok intervensi, yang tidak dilakukan Inisiasi Menyusu Dini diketahui nilai Mean atau rata-rata 11,30 dan nilai median 11,00 . Sedang kan involusi uterus intervensi dilakukannya Inisiasi Menyusu Dini diketahui nilai Men atau rata-rata 9,30 nilai median 9,00 Hal ini menunjukkan adanya peningkatan jumlah involusi uterus setelah di lakukan Inisiasi Menyusu Dini dimana Inisiasi Menyusu Dini merupakan satu tindakan untuk terjadinya involusi uterus, hal ini di karenakan Inisiasi Menyusu Dini satu satu terjadinya involusi uterus yang dilakukan sedini mungkin sesuai teori (walyani purwostuti,2018).

Berdasar hasil penelitian Nelwatri (2013) diketahui bahwa terjadi penurunan fundus uteri pada ibu nifas hari keenam yang dilakukan inisiasi menyusui dini adalah 10,54-1,103 cm sedangkan tinggi fundus uteri pada ibu nifas yang tidak dilakukan Inisiasi Menyusu Dini adalah 13,33-1,129 cm. Hasil ini menunjukkan penurunan tinggi fundus uterus sekitar $2,79 \mathrm{~cm}$ pada ibu yang melakukan Inisiasi Menyusu Dini dibandingkan yang tidak. 
Dalam asumsi penelitian bahwa ada pengaruh Inisiasi Menyusu Dini terhadap involusi uterus pada ibu postpartum, terjadi penurunan involusi uterus karena pemberian Inisiasi Menyusu Dini terhadap ibu postpartum yang secara otomatis akan merangsang keluarnya hormone oksitosin yang akan merangsang uterus untuk berkontraksi, sehingga terjadi lah penurunan uterus.

\section{KESIMPULAN}

a. Rerata hasil pengukuran Involusi Uteri pada kelompok kontrol adalah $11,30 \mathrm{~cm}$

b. Rerata hasil pengukuran Involusi Uteri pada kelompok intervensi adalah $9,30 \mathrm{~cm}$.

c. Ada pengaruh yang signifikan terhadap hasil pengukuran involusi uteri pada kelompok kontrol dan kelompok intervensi yang dilakukan IMD pada ibu post partum di Klinik Tutun Sehati Tahun 2019 dengan nilai $p$-value $=0,003(p<0,05)$.

\section{DAFTAR PUSTAKA}

Dewi, Vivian Nanny Lia, Sunarsih, Tri. 2011. Asuhan Kebidanan Ibu Nifas, Jakarta : Selemba Media.

Depkes RI. 2015. Profil Kesehatan Indonesia. Jakarta

Dwi Sunar Prastyono. 2012. ASI Ekslusif. jogyakarta : Diva Press.

Endang Purwoastuti. 2018. Asuhan Kebidanan Masa Nifas Dan Menyusui. jogyakarta : PT.Pustaka Baru.

JNPK-KR.2012. Asuhan Persalinan Normal dan Inisiasi Menyusui Dini. Jakarta:

Jhplego. World Health Organization. 2015. Maternal Mortality. In: Reproduction Heald and Dwi Sunar Prastyono Research, editor.Geneva.

Kemenkes. 2016. Profil Kesehatan Indonesia. Jakarta : Kemenkes.

Kementerian Kesehatan RI. 2014. Mother Day. Jakarta.

Kemenkes RI. 2013. Riset Kesehatan Dasar. Jakarta.
Mochtar, Rustam, 2010. Sinopsis Obstietri Fisiolagi Patologi, Jilid 1.EGC. Jakarta

Nelwatri, Helpi. 2013. Pengaruh Inisiasi Menyusu Dini (IMD) Terhadap Involusi Uterus Pada Ibu Bersalin Di Bps Kota Padang. http://ejournal.kopertis10.or.id/i ndex.php/jit/article/view/2.

Nina Siti Mulyani. 2018. ASI dan Panduan Ibu Menyusui. Jogyakarta :Nuha Medika.

Riskesdas. 2013. Badan Penelitian dan Pengembangan Kesehatan Kementerian RI tahun 2013.Diakses: 19 Oktober 2014, darihttp://www.depkes.go.id/res ources/download/general/Hasil\% 20Riskesdas\%20 2013.pdf.

Sitti Saleha. 2009. Asuhan Kebidanan Pada Masa Nifas. Jakarta : Selemba Medika.

Sujiatini. 2016. Asuhan Kebidanan Persalinan. Yogyakarta : Nuha Medika.

UNICEF. 2013. Improving Child Nutrition: The achievable imperative for global. Jakarta.

Vivian Nanny Lia Dewi . 2011. Asuhan Kebidanan Pada Ibu Nifas. Jakarta : Salemba Medika.

World Health Organization (2017). Mental disordesfach sheets, World Health Organization.

World Health Organization. 2015 Maternal Mortality. In: Reproduction Heald and Research, editor.Geneva.

Yanti. 2018. Asuhan Kebidanan Persalinan.Yogyakarta :Pustaka Rihama. 